\title{
Noongar and non-Aboriginal people going along together (Ngulla wangkiny, ni, katitjin Noongar nyidyung koorliny, kura, yeye, boorda)
}

\section{Len Collard and Dave Palmer}

\section{Introductions}

Len: Kaya. Yeye. Nidja Ngunnawal boodjar ngulla nyinniny.

Ngulla koort kwoppa koorliny Canberra 2013. Ngulla wangkiny kura Noongar wam koorliny. Nidja Dave. Nyuny kwel Len. Ngulla koorliny birrit or Perth. Ngulla karleep Whadjuk Nyungar boodjar.

Dave: Hullo, we start by acknowledging Ngunnawal as the bosses for country in Canberra. Our hearts were very happy to visit in 2013 and to meet people and talk about Noongar and others going along together in the past. Len and I are from Perth in Western Australia. Noongar country is where our home fires burn. 
We acknowledge that we first presented the ideas for this paper in Ngunnawal country where their home fires burn. We thought about it and wrote it in Noongar country.

Len: The conference organisers were right to observe that the history of colonial interaction in this country has included many instances of various Indigenous intermediaries (guides, translators, cultural attaches, workers, entertainers, friends and hosts) acting to assist and support the lives of the 'newcomers'. For example, my moort (family) has an extended history of offering katitjin (Noongar knowledge) about our boodjar (country), offering local sources of daartj wer mearniny (food, both meat and vegetables), kep (water) karla (warmth), mia (shelter), balyi (protection from danger), kwoppa wiern (spiritual goodness) and djooripin moort (familial and emotional support).

Dave: In the early years of colonial exploration there was no shortage of instances where those who came to Noongar country were either cruel or openly hostile. ${ }^{1}$ On the other hand, as Noongar accounts and Wedjela diaries, journals and other historical documents demonstrate, many had a deep reliance on Noongar hospitality, knowledge and labour. ${ }^{2}$

In this paper we want to do two things. We would like to revisit some of the historical accounts of life in early colonial south-west Australia, drawing out instances where Noongar took on 'centre stage' in development, shaping the cultures, language, enterprise and everyday experiences of others. We also want to extend the way in which these early texts are interpreted by 'talking back' to the old voices through the adoption of what we will call Noongar hermeneutic methods. Most scholars who turn their attention to intermediary contact on the colonial frontier rely exclusively on an interrogation of the archival material. Some have buttressed this with recognition of the oral accounts of later years. What we want to do is propose additional methods for entering into conversations with the past, inspired by how the 'old people' (Noongar elders who have passed down their practices) read the country, listen to it speak and make assessments about what has happened.

Len: As a consequence, the style and methods adopted are a little unconventional. We draw on the cultural experience and knowledge gained from koorliny yirra Noongar (growing up Noongar), katitjin Noongar wangkiny (learning to speak the language) and katitjin Noongar (interpreting the 'evidence' using Noongar ways of thinking). We have also used the oral accounts of other Noongar as well as material from the written historical record. Some Western-trained historians

\footnotetext{
Bates 1992; Moore 1974 [1884]; Green 1984.

Haebich 1988; Hodson 1993; Pope 1993.
} 
might not always accept the evidentiary strength of this approach. What is important here is that we are trying to move in and out of these traditions, Noongar and non-Noongar history making.

\section{Boorna wangkiny ni: Listening to what has been written}

Dave: We should start by explaining where and whom we are talking about.

Len: Those who identify as Noongar call the south-west corner of Western Australia their karla (where their home fires burn). Noongar are those who have moort and cultural affiliations to the first people who have lived in the region for at least 40,000 years. Noongar boodjar runs from as far north as Geraldton, southeast to the small town of Noongar on the Great Eastern Highway all the way as far east as Esperance on the south coast. This area takes in much of the state of Western Australia's wheat belt, many hundreds of kilometres in coastline, the state capital, Perth, and the regional cities of Bunbury and Albany. ${ }^{3}$

The word 'Noongar' is translated by many as 'people' and is consistently used by those with affiliations to 14 dialect groups across the greater cultural block of Noongar. To Noongar, boodjar is critically important. In the old days each family group had their own kaleep (or camping places), which had enormous importance for them. For Noongar their moort and katitjin is intricately tied up with boodjar. This relationship is made manifest in the way people maintain their obligations to each other, their place and people's conduct. In kura (the 'old days') all Noongar were born into a complex system of social groupings that ensured each was a member of a 'skin' or moiety group. As well as sharing a place in these groups with other humans, Noongar 'skin' includes flora, fauna, rocks, rivers and places. In this way, different parts of boodjar are moort related in the same way as brothers and sisters, uncles and aunties. For many Noongar their 'old people' (those who have passed away) have symbolically and literally moved back to dwelling amongst the rocks, the trees and animals. For many Noongar this means that to visit and care for boodjar is to visit and care for moort (the old people). ${ }^{4}$

Dave: We also know from the colonial record that Noongar life has changed dramatically since non-Aboriginal people first came to the area to live in 1829 . Long-held traditions, practices and language have been under enormous pressure, particularly between the 1850s and 1940s when families were forced

Collard 2007b; Hallam 1979.

Collard 2007a, 2007b. 
to relocate away from their karla (or homelands). Many continued to be removed from their moort through generations of government policy that involved forced family separation. These shifts in life have been recorded in oral traditions, song and dance traditions and in fine artwork such as the 'Carrolup style' of painting that emerged from the Carrolup Mission near Katanning. ${ }^{5}$

Len: However, Noongar connection to boodjar, moort, katitjin and wangkiny (language) has proved remarkably resilient, managing to maintain, reignite and renew itself. ${ }^{6}$ Often this is most clearly expressed in Noongar forms of art, craft, music-making, theatre, film and language revival. ${ }^{7}$ However, what many people don't realise is that these ways of being and thinking are still incredibly powerful in shaping the way that people do history and think about their relationship to the past.

Dave: So why are these Noongar ideas so important when thinking about history in the south-west? Surely they don't alter the facts do they?

Len: On the contrary, these ideas have everything to do with the facts. How can we expect to make any sense out of what has happened with, to and by Noongar if we have no idea of the fundamental concepts and 'epistemological' frames that make sense to Noongar?

Dave: Well then, let us have a look at some of these ideas by turning to the early history of Noongar dealing with outsiders.

\section{Moort ni: Listening to this Noongar family and people's oral accounts}

Len: I want to tell you a story from kura or a long time ago. Many Noongar remember this story and tell it in a number of ways. It might help to set the scene. The account is also on the colonial record.

When they first realised that the big ships carried people, Noongar thought the coastal explorers were djanga or returned spirits of their noitj moort or dead relatives coming home again. Some were happy, and they welcomed the white spirit beings as members of their family. Noongar would have known that they had important protocols to carry out. It was their responsibility to teach their moort all about Noongar katitjin of the boodjar, because they had obviously

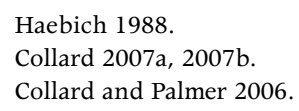


forgotten everything when they had 'died'. Some were frightened and ran and hid. Others invited the djanga back into their country and into their worlds literally as their kin or moort. They invited them to relearn about their boodjar.

Clearly without Noongar katitjin or help the djanga were dwangabert, meeowbert and kaat warra djanga. They were blind, deaf and spirits without knowledge. Barl bidiboort wah? Or they stumbled about in the bush as if they were lost. Sometimes Noongar helped the newcomers, reminding them of where they were and how to stay safe. Noongar still tell this story today and elaborate on different parts.

Dave: The explorer and later governor of South Australia and New Zealand George Grey realised as early as December 1838 that Noongar understood the newcomers as returned relatives. This he claimed was a perfectly reasonable conclusion given they had such profound connections to their country and an enormous reticence to give up or leave their karleep (home camp) for long periods. He recorded that:

They themselves never having an idea of quitting their own land, cannot imagine others doing it; - and thus when they see white people suddenly appearing in their country, and setting themselves down in particular spots, they imagine that they must have formed an attachment for this land in some other state of existence; and hence conclude the settlers were at one period black men, and their own relations. ${ }^{8}$

I remember when I first began to look at historical documents I was immediately struck by the extent to which Noongar seemed open and hospitable to outsiders. Indeed, Noongar seem to have an extended history of welcoming and offering hospitality to outsiders. ${ }^{9}$ I was also struck by the richness of the accounts from these times in the stories of contemporary Noongar. ${ }^{10}$ Immediately I was confronted with the question of why this might have been so. Len, do you have an explanation?

Len: Part of the reason lies in the fact that Noongar were well accustomed to regular visits from wam or 'outsiders'. Noongar regularly visited country that was controlled by others, sometimes travelling hundreds of miles. Unless you have an understanding of the Noongar idea of moort, you might be forgiven for thinking that people lacked a bit of order or simply meandered about the place in a state of child-like utopian bliss. However, this was not the case. My old Pop, Tom Bennell, used to talk about how Noongar would regularly visit others, partly out of obligation to their moort, partly to carry out ceremonial, social

8 Grey 1841: 302-303.

9 Grey 1841; Green 1984.

10 Bennell 1993; Walley 1995; Collard 2007a, 2007 b. 
and economic 'business' and partly to help out with the sustaining of boodjar. Along with this is the obvious importance of story, song and performance in the life of Noongar family. Moort is one of the centre pieces of Noongar life both as a way of setting up relationships so wam (strangers) are incorporated, and of recording and transmitted through oral means amongst family and across the generations. ${ }^{11}$

Dave: This is also well accounted in the colonial record. According to archaeologist Sylvia Hallam, before colonisation meetings between different Noongar groups were highly structured events, 'with elements of ceremonial preparedness for conflict, formal peace-making, reciprocal exchange of gifts, and sometimes actual conflict and resolution of conflict ${ }^{\prime} .{ }^{12}$ Outsiders were given a place within Noongar kin structures, facilitating participation in such things as education and knowledge attainment, marriage and sexual relationships, involvement in important meetings, the gathering and distribution of food, economic and social reciprocity, attendance at funerals, intergroup conflict and indeed contact and avoidance of others. ${ }^{13}$ These stories of wam were also critical in the songs, dances and narratives that have continued to filter down from generation to generation. ${ }^{14}$

Len: This practice of comparing the archival records with contemporary oral accounts is not particularly novel for historians.

\section{Wangkiny nitja boodjar ni: Listening and talking back to this country}

Len: As mentioned earlier, in contrast to Western ideas about country as inanimate Noongar see it as part of our moort. Before we were born our wiern or spirit dwells in country. Our 'old people', or those who have passed away, go back to nyinniny (sit down) in country. Part of the job of these boordier (bosses of country) is to watch over their moort and keep us safe. They do this in many ways, including communicating with us through the wind, animals, our kanya (feelings) or koornda (sense of shame) and various other signs. ${ }^{15}$

Dave: So are you saying that it is possible to draw upon the 'old people', those who are no longer with us, in our history work?

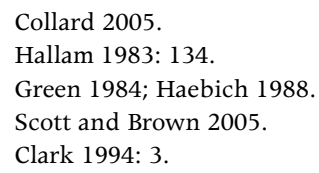


Len: Ngulla boodjar ngulla boordier (our country is our boss and guide). Noongar learn a great deal by talking to country, literally singing out to the 'old people' and listening for its response. My konk Whadjuck/Balardong (my Whadjuck and Balardong uncle) Sealin Garlett reminded one time about his own experiences about this very matter telling me that:

my Grandma (Yurleen) used to say this was to be passed on to her children and her grannies ... there are places where you find serenity; where you find a sense of belonging ... that this is a part of our place, this is a part of our area, our culture. Nitcha boodjar koonyarn nitcha koorl buranginy boodjar karluk maya koonyarn wah. Deman deman and maam wiern kia moort koonyarn. Deman and maam noonookurt, boodjar koonyarn karla koorliny. Koorlongka boorda gneenunyiny. Those words say that this is my country where I belong. This is deman and maam, my grandmother and grandfather's land, this is their land where their spirits move now. Boorda or later on, this is going to be the responsibility of my children and my children's children, their home and this place will always be linked to their spirit. ${ }^{16}$

As I said before, Noongar are literally related to country. We talk with it, walk with it, feed it and get nourished by it. Country reveals things to us. Let me explain some more. Before you and I were born we dwelt within country as spirits. When we pass away we head back to this form. Each tree, animal, rock and piece of vegetation are moort. We have brothers and sisters that are certain trees, rocks that are my grandparents, animals that are my parents.

Dave: Anthropologist Deborah Bird Rose puts it beautifully when she says:

In Aboriginal English, the word 'country' is both a common noun and a proper noun. People talk about country in the same way that they would talk about a person: they speak to country, sing to country, visit country, worry about country, grieve for country and long for country. People say that country knows, hears, smells, takes notice, takes care, and feels sorry or happy. Country is a living entity with a yesterday, a today and tomorrow, with consciousness, action, and a will toward life. ${ }^{17}$

Len: Rose observes that the process of moving on country not only involves the young and their living elders 'going along together', it also demands we go along together with elders and ancestors long passed away. ${ }^{18}$ Important here is the conception that the dead are an integral part of the maintenance of life and the education and experience of the young and living. It involves 'paying dues' to the ancestors, respecting the cycle of life in death and death in life and

\footnotetext{
16 'Nidja Beeliar Boodjar Noonookurt Nyininy', Murdoch University, wwwmcc.murdoch.edu.au/ multimedia/nyungar/.

17 Rose 2002: 14.

18 Rose 2004.
} 
learning about their obligations to pass this on to those who 'come behind' ${ }^{19}$ To do this we sing out, announcing our presence, recognising those who have passed and seeking guidance about how to keep ourselves safe. We also listen to what country has to say to us, using language and singing out. Through this the history of a place becomes revealed.

Dave: We could describe this as forming a kind of hermeneutic circle, an interpretive process that involves speaking out and listening for a response to language. According to philosopher Hans-Georg Gadamer, what is crucial in any interpretive exercise 'is the process of identifying and linking the alien with the familiar information, selectively focusing the interpreters' search for new perspectives' ${ }^{20}$ This depends on people's enthusiasm to be open to new possibilities. ${ }^{21}$ Gadamer might say of our interest in this paper, we need to playfully enter into dialogue with what some consider being alien or unfamiliar sources (Noongar language, country and concepts), thus allowing us to talk back to the historical texts until new understanding emerges. ${ }^{22}$

Perhaps one way to illustrate this is to turn to the way you interpret country through speaking and listening back to the Noongar sound(s) of place names.

Len: A specific contribution of Noongar in the south-west of Western Australia has been through the naming of places. Indeed more than 60 per cent of place names in the south-west are of Noongar origin. Today, when we look around Western Australia many towns, suburbs, freeways and street signs use Noongar names. In this way country speaks to us about its history. So prolific is the penetration of Noongar into the type of English spoken in the south-west that one could read a street directory and learn a great deal about country. Of course this is only possible if we have an understanding of language. However, it is not always this simple. Various forms of spelling have been used to record place names. Sometimes this Europeanisation of places makes it hard to figure out what a place means.

Dave: You have taught me the practice of speaking aloud the name of a place, sounding it out so as to help aurally process what the words might be. This often works to magically illuminate what a word might mean despite the fact that it has been written in a strange way.

Len: One example is the place name Manjoordoordap which is the old name for the modern place we know as Mandurah. According to the claims made by historians, Mandurah means a place of trade and festivities. By speaking out

19 Muecke 1997, 2004.

20 Regan 2012: 293.

21 Gadamer 2004: 4.

22 Gadamer 2004: 269. 
this word and listening to how it sounds its meaning has come to me. Manda is the word for gathering to exchange. Djookoord is a wife or a female lover. Ap, up or $p$ is the location of a place. Taken together and spoken out loud a much richer meaning revealed itself to us. In this way, Manjoordoordap speaks to us as a source of its own history, outlining the importance of the area as a place for romantic interludes during times of trade and exchange and cultural festivities. Interestingly, this continues to be the case to this very day, as Mandurah is a place that attracts lovers to meet, enjoy time by the ocean and relax in each other's company. ${ }^{23}$

Dave: It is through speaking and listening that meaning can become clearer. In this way the process of interpreting history literally demands listening to the sounds of words to explore the multitude of possible Noongar meanings hidden behind the oral and written pronunciation. In this way you are literally having a conversation with country, using your voice in a process of call and response.

\section{Gnarl koorliny katitjin baranginy ni: Sweat, moving and grasping hold of this thing}

Len: Being on boodjar is also important because it helps invigorate and make the country safe, productive and responsive. To be on country includes the act of keeping stories for that country alive. To stay away from country is to risk these stories passing away.

Dave: So in this way the business of doing history makes it necessary to be on and around country?

Len: One set of concepts that is strongly connected to ideas about boodjar is what we would call ngulla koorliny (going along together). For as long as I can remember an important ethic for growing up was that individuals go along on country with others, particularly those that are older and know what they are doing. I remember being taught as kids that country does not look kindly on you wandering off on your own. We were instructed in no uncertain terms that if we were to go off somewhere we do it in twos and threes. If something goes wrong then there is always someone to look after you. If one person doesn't know something then there is more chance of you surviving if there are two or three of you and you were with someone with experience.

Dave: What has this got to do with interpreting history in the south-west? 
Len: To put it simply, unless you produce sweat on country you are not going to find out anything about that place. This old Noongar practice of going along on country to understand that country and its history is a useful elixir to problems that come from spending all our time in archives and in front of our computers. When on country we get to see things that would have been instrumental in shaping what went on. Through listening to birds, the shape and strength of wind, seeing the species and experiencing the climate we get a clearer idea of how that country was used and what would have happened. Going out on country also helps us to see the presence of Noongar influence a little more clearly. It is also a good way of understanding the geographical and climatic context that confronted people.

Dave: It's also a greater way to open up our imagination to what might have gone on. For example, I remember walking with you through places like the Pinjarra massacre site, various parts of the Swan River and King George's Sound to help us get a sense of how Noongar would have experienced first sightings of the colonists, where they may have been able to position themselves and take note from topographical signs. This, combined with your knowledge of seasons, prevailing winds and hunting practices, helped us get a great sense of what was likely to have happened. It also gave me a strong sense of how important Noongar would have been to those who did not know the country. It helped me see how it is that Noongar have such a deep history of being next to colonists at many points in the history of the south-west.

Len: Being on country with Noongar changed the relationship some early colonists had with Noongar. As soon as colonists started exploring country it became apparent that Noongar (particularly the young and fit) possessed very sophisticated knowledge of immense value. Noongar presence in an area became a sign that food, water, other valuable resources, and knowledgeable men and women were close to hand..$^{24}$ People like John Drummond, an early settler from York, came to realise that 'good land to the aborigines [sic] was good land for them'.$^{25}$ The most popular areas included King George's Sound, the Swan and Murray estuaries, the Avon Valley, Leschenault Inlet, the Vasse district, and the rich country around Pinjarra. ${ }^{26}$

Dave: The Western Australian writer Jesse E. Hammond records that Wedjela travellers, shepherds, merchants and explorers looked for well-marked Noongar bidi or foot-tracks 'like cattle-pads and just as plain' ${ }^{27}$ Indeed, a good deal of these tracks formed the basis many of today's main roads. ${ }^{28}$

\footnotetext{
Markey 1976: 9.

Wollaston cited in Hallam 1991: 48.

Markey 1976: 8.

Hammond 1933: 18.

Clarke 1996: 76.
} 
For example, when surveyor Ensign Dale first travelled east from the Swan River through the rolling hills and into the Avon Valley, he commented on the potential for utilising country already worked by Noongar. ${ }^{29}$ Likewise, John Bussell saw the potential for exploiting pasture around Talanup (today known as Augusta) which had been carefully tended by Noongar firestick hunting. ${ }^{30}$ Patrick Armstrong argued that Noongar created a 'mosaic of plant communities' highly conducive to European systems of agriculture. He claimed that the complex environmental systems were due to 'variations in the manner and frequency of firing as much as to differences of soil, topography and water relations' ${ }^{\prime}{ }^{31}$

Len: In 1836 Lieutenant Henry William St Pierre Bunbury was stationed in the York, Pinjarra and Busselton districts, and over the course of the next 18 months undertook various exploratory excursions in the region. ${ }^{32}$ Whilst in Noongar country he noted that:

By these fires ... the country is kept comparatively free from underwood and other obstruction, having the character of an open forest through most parts of which one can ride freely; otherwise in all probability, it would soon become impenetrably thick, and ... the labour cost of clearing would be so greatly increased as to take away all the profit, and it would change the very nature of the country, depriving it of the grazing and pastoral advantages it now possesses ... It is true that we might ourselves burn the bush, but we could never do it with the same judgment and good effect of the Natives. ${ }^{33}$

This is neither hardly surprising nor terribly unique to exploration in the south-west of Australia. We see similar patterns in the attempts of early British colonial 'explorers' and administrators. Indeed, Captain Arthur Phillip, the first Governor-Designate to the colony of New South Wales, was instructed by his authorities to seek out signs of Aboriginal people so that their knowledge could be turned to the advantage of the newcomers. ${ }^{34}$ Long has the West recognised the value that the East has to itself. ${ }^{35}$

\footnotetext{
Garden 1979.

Bussell 1833.

Armstrong 1978: 31.

Cammilleri 1966.

Markey 1976: 11.

Rolls 1998: 64.

Voltaire cited in Clarke 1997: 3.
} 
INDIGENOUS INTERMEDIARIES

\section{Kanya koort weirn ni: Listening to this feeling in and of the heart and spirit}

Dave: Len, the word intermediary has its roots in the medieval Latin intermediatus: 'lying between'. Likewise, the business of being intimate takes its meaning from the Latin intimus 'inmost' (adj.) or 'close friend' (n.). In the 1600s the idea of intimacy was often used as a euphemism for 'sexual intercourse' ${ }^{36}$ What about matters of the heart and soul?

Len: An idea that I have been raised with is the importance of kanya koort. Thinking and knowledge exchange works best when our koort (hearts) are kanya (in good spirit). Our capacity for understanding the past is very much tied up with our ability to use our spirit, what we often describe as our emotions and intuition.

Dave: My friends from the Kimberley talk about the importance of the liyarn, a part of the human body where the spirit sits, in knowledge. Without a healthy liyarn one cannot understand country, history and culture. Conversely, an unhealthy liyarn can lead us to make mistakes, get confused and misjudge where we are.

Len: Yes, that is like our kanya or wiern, our spirit. Healthy kanya and koordan comes from being on country, being with our family and singing on and for country. You rely on it and it becomes stronger and more illuminating. If we try and go about finding things out about country without our old people and without listening to our kanya and koordan then we will become kaat wara, we will get confused.

I have no doubt Noongar kanya and koordan have been important to nonNoongar. In the early days they were often physically and socially isolated from contact with others. It is true that this isolation was not good for their spirit. It drove many to fear Noongar. As a result many came to rely on Noongar for friendship, comfort and sexual intimacy.

Dave: There are many examples of this. Noongar like Tommy Windich rode at the head of many important exploration parties led by people like the Forrest brothers. ${ }^{37}$ He would have combined his keen observation and navigation skills with this approach of 'intuiting' and reading the country's many signs.

36 Etymoline 2014.

37 Wilson 1981: 115. 
Len: This is right: 'feeling' our way around country and around history is much more important than we often admit. Indeed, we use metaphors that reveal our reliance on kanya and koordan. Historians 'follow leads', 'track down' the truth, head down a particular 'path', 'pick up' clues and 'dig up' the facts. Perhaps we need to be a bit more honest, take some clues from Noongar and get out on country as a way of doing history.

\section{Kura, yeye, boorda: From the past, until today and into the future: Conclusion}

Len: Let me read to you what the early Quaker traveller James Backhouse observed about the influence of Noongar:

A few of the boys assimilate themselves, in some degree, with the servants and the Settlers, and the little Blacks are often the playfellows of the white children; but even, under these circumstances, the Blacks are growing up in much the same state of barbarism as their ancestors; and it is a question, whether the white children do not learn more of barbarism from the Blacks, than the Blacks acquire of civilisation from the Whites. ${ }^{38}$

Dave: If early colonial historians were to have embraced contemporary terminology, they may well have described some Noongar as expert consultants, cultural attachés, diplomatic peacekeepers or historians. During very early colonial life in the south-west, many non-Aboriginal people, many parties of 'explorers', and many government officials were assisted in some way by Noongar guides and cultural experts. Indeed, as historian Ian Clark reminds us, those exploration parties which eschewed advice and help from Aboriginal people, such as the ill-fated Burke and Wills expedition, failed. ${ }^{39}$

Len: Noongar acting as guides set up the pattern for many later engagements which saw distinctly Noongar knowledge and expertise become important for people living in the south-west of Australia. ${ }^{40}$ We could also say that they offered insights to those of interested in talking about this history. We might say:

Noonook 'kura boordier'. Noonoook koorliny bulla. Noonook boorna wangkiny ni, moort ni, boodjar ni, wangkiny ni, geenunginy boordier ni, koorliny katitjin baranginy ni, wiern kanya and koordan koort.

38 Backhouse 1843: 539-540.

39 Clark 1994: 21.

40 Richards 1993: 56. 
Dave: Yes, what you say is 'later on whitefella gain much knowledge because they followed along behind Noongar, being taken in as family, taught language and introduced to country, becoming strong in knowledge and spirit'. Noongar have a long involvement in offering their methods of coming to 'know' about things. Non-Noongar have a long involvement in drawing upon this intelligence and helping it to open up knowledge. If we want to better understand the past surely we could do well to draw upon Noongar methods and combine listening to the written sources, listening to family accounts, listening to country, speaking and listening out loud to country, making some sweat and getting out of the archives, listening and looking for signs of Noongar agency and using our spirit and heart to see.

Len: Kia, boorda ngulla kwoppa Noongar wangkiny, ni, katitjin - kura, yeye, boorda. Boorda noonarkoort geeninginy nitja wah?

Later on then we will be able to speak, listen and think wisely about the connections between yesterday, today and the future. Later on you will see, eh?

\section{References}

Armstrong, Patrick H. 1978, 'The Aboriginal practice of firing the bush: the evidence of early newspapers', Journal and Proceedings of the Royal Western Australian Historical Society 8(2): 31-34.

Backhouse, James 1843, A Narrative of a Visit to the Australian Colonies. Hamilton, Adams and Co., London.

Bates, Daisy 1992, Aboriginal Perth: Bibbulmun Biographies and Legends, Peter J. Bridge (ed.), Hesperian Press, Carlisle.

Bennell, Tom 1993, Kura, revised edition, Glenys Collard (ed. and comp.), Nyungar Language Centre, Bunbury.

Bussell, J. 1833, 'Report of an expedition to the northward from Augusta by Mr J. C. Bussell', in Journals of Several Expeditions Made in Western Australia During the Years 1829, 1830, 1831 and 1832: Under the Sanction of the Governor General Sir James Stirling, Containing the Latest Authentic Information Relative to that Country, Accompanied by a Map, Joseph Cross (ed.), Facsimile, University of Western Australia Press, Nedlands, 178-185.

Cammilleri, Cara 1966, 'Bunbury, Henry William St Pierre (1812-1875)', Australian Dictionary of Biography, National Centre of Biography, The Australian National University, adb.anu.edu.au/biography/bunbury-henrywilliam-st-pierre-1846/text2137, accessed 28 July 2014. 
Clark, Ian D. 1994, Sharing History: A Sense for All Australians of a Shared Ownership of Their History, Australian Government Publishing Service, Canberra.

Clarke, John James 1997, Oriental Enlightenment: The Encounter between Asian and Western Thought, Routledge, London.

Clarke, Peter 1996, 'Adelaide as an Aboriginal landscape', in Terrible Hard Biscuits: A Reader in Aboriginal History, Valerie Chapman and Peter Read (eds), Allen and Unwin, St Leonards, 69-93.

Collard, Len 2005, 'Nidja beeliar boodjar noonookurt nyininy: A Nyungar interpretive history of the use of boodjar (country) in the vicinity of Murdoch University, Perth, Western Australia', wwwmcc.murdoch.edu.au/ multimedia/nyungar.

-2007a, 'Wangkiny ngulluck Nyungar nyittiny, boodjar, moort and katitjin: talking about creation, country, family and knowledge of the Nyungar of south-western Australia', in Speaking From the Heart: Stories of Life, Family and Country, Sally Morgan, Tjalaminu Mia and Blaze Kwaymullina (eds), Fremantle Arts Centre Press, North Fremantle, 279-298.

-2007b, 'Kura, yeye, boorda: from the past, today and the future', in Heartsick for Country: Stories of Love, Spirit and Creation, Sally Morgan, Tjalaminu Mia and Blaze Kwaymullina (eds), Fremantle Arts Centre Press, North Fremantle, 59-80.

Collard, Len and David Palmer 2006, 'Kura, yeye, boorda, Nyungar wangkiny ngulla koorlangka: a conversation about working with Indigenous young people in the past, present and future', Youth Studies Australia 25(4): 25-32.

Gadamer, Hans-Georg 2004, Truth and Method, second edition, Sheed and Ward Stagbooks, London.

Garden, Donald S. 1979, Northam: An Avon Valley History, Oxford University Press, Melbourne.

Green, Neville 1984, Broken Spears: Aborigines and Europeans in the Southwest of Australia, Focus Education Services, Perth.

Grey, George 1841, Journals of Two Expeditions of Discovery in North-West and Western Australia, During the Years 1837, 1838 and 1839, T. and W. Boone, London, 2 vols. 
INDIGENOUS INTERMEDIARIES

Haebich, Anna 1988, For Their Own Good: Aborigines and Government in the South West of Western Australia 1900-1940, University of Western Australia Press, Nedlands.

Hallam, Sylvia J. 1979, Fire and Hearth: A Study of Aboriginal Usage and European Usurpation of South-Western Australia, Australian Institute of Aboriginal Studies, Canberra.

1983, 'A view from the other side of the western frontier: or "I met a man who wasn't there ..."', Aboriginal History 7: 134-156.

-1991, 'Aboriginal women as providers, the 1830s on the Swan River', Aboriginal History 15(1): 38-53.

Hammond, Jesse E. 1933, Winjan's People: The Story of the South-West Australian Aborigines, Imperial Printing Co., Perth.

Hodson, Sally 1993, 'Nyungars and work: Aboriginal experiences in the rural economy of the Great Southern Region of Western Australia', Aboriginal History 17(1): 73-92.

Markey, D.C. 1976, More of a Symbol than a Success: Foundation Years of the Swan River Colony, Mount Lawley College of Advanced Education, Perth.

Moore, George Fletcher 1978 [1884], Diary of Ten Years of an Early Settler in Western Australia, University of Western Australia Press, Nedlands.

Muecke, Stephen 1997, No Road (Bitumen all the Way), Fremantle Arts Centre Press, South Fremantle.

2004, Ancient and Modern: Time, Culture and Indigenous Philosophy, University of New South Wales Press, Sydney.

Pope, Brian 1993, 'Aboriginal message and mail carriers in South Western Australia in the early and mid-nineteenth century', Portraits of the South West: Aborigines, Women and the Environment, Brian de Garis (ed.), University of Western Australia Press, Nedlands, 57-77.

Regan, Paul 2012, 'Hans-Georg Gadamer's philosophical hermeneutics: concepts of reading, understanding and interpretation', Meta: Research in Hermeneutics, Phenomenology and Practical Philosophy 4(2): 286-303.

Richards, Ronald 1993, Murray and Mandurah: A Sequel History of the Old Murray District of Western Australia. Mandurah City Council, Pinjarra.

Rolls, Mitchell 1998, 'Cultural colonisation: Monica Furlong and the quest for fulfilment', Australian Feminist Law Journal 11: 46-64. 
Rose, Deborah Bird with Sharon D'Amico, Nancy Daiyi, Kathy Deveraux, Margaret Daiyi, Linda Ford and April Bright 2002, Country of the Heart: An Indigenous Australian Homeland, Aboriginal Studies Press, Canberra.

Rose, Deborah Bird 2004, Reports from a Wild Country: Ethics for Decolonisation, University of News South Wales Press, Sydney.

Scott, Kim and Hazel Brown 2005, Kayang \& Me, Fremantle Arts Centre Press, Fremantle.

Walley, T. 1995, 'The good samaritan robin redbreast (demlark): A New Norcia Dreamtime story', in A Town Like no Other: The Living Tradition of New Norcia, David Hutchison (ed.), Fremantle Arts Centre Press, South Fremantle, 37.

Wilson, Helen Wood 1981, Bushman Born, Artlook Books, Perth. 
This text is taken from Indigenous Intermediaries: New Perspectives on Exploration Archives, edited by Shino Konishi, Maria Nugent and Tiffany Shellam, published 2015 by ANU Press, The Australian National University, Canberra, Australia. 